\title{
The new international tax regime: analysis from a power-basis perspective
}

\author{
Akira Matsuoka ${ }^{1}$ iD \\ Received: 19 October 2020 / Accepted: 12 April 2021 / Published online: 30 April 2021 \\ (c) The Author(s), under exclusive licence to Springer Nature Switzerland AG 2021
}

\begin{abstract}
Scholars of international relations have not cultivated the groundwork of international taxation. However, the Organization for Economic Cooperation and Development's Base Erosion and Profit Shifting (BEPS) Project, Post-BEPS, and the Common Reporting Standard system, have attracted political attention on an international level. The purpose of this paper is to explain the recently formed and still being formed international tax regime by applying international regime theory from a power-based perspective. This study addresses the regime in two aspects: tax rulemaking and tax administration. The author uses qualitative discussion, breaking down the recent international tax regime issues for each sub-regime. Through the discussion, this research implies that major economic powers, pressures of fear of being labeled uncooperative, the force of theoretically grounded idea regarding a fundamental international tax principle, and the desperate need for tax authorities to ensure taxpayer and money flow transparency, are assisting the formulation of the new international tax regime.
\end{abstract}

Keywords The OECD BEPS Project · Post-BEPS · CRS · International regime · Realism

JEL Classification F50 $\cdot$ F53 $\cdot$ G18 $\cdot$ H26 $\cdot$ H29 $\cdot$ K34

\section{Introduction}

The scandals of the international tax avoidance by US-based multinational enterprises (MNE) around 2010 (Committee of Public Accounts, House of Commons n.d.; Bergin 2012), were quite sensational. Tax havens, whose distinctive features were described by Remeur $(2018,3)$ in a briefing from European Parliamentary Research Service, are "low or zero taxation, fictitious residences (with no

Akira Matsuoka

a-matsuoka@sozo.ac.jp

1 Toyohashi Sozo University, 20-1, Matsushita, Ushikawacyo, Toyohashi, Aichi 440-8511, Japan 
bearing on reality) and tax secrecy." This became more popular, as the Organization for Economic Cooperation and Development (OECD)'s Project on Harmful Tax Practices gained steam. However, the sensation of these scandals upset members of the public, even those with less tax expertise, as well as the international society. Thus, from a micro-level, Starbucks faced boycotts in the UK after the Seattle-based coffee MNE was exposed to international tax avoidance (BBC 2012). Google faced anger of the people of France because its international tax avoidance scheme was uncovered around the same period (Associate Press 2012; Drucker 2012). Anti-MNE efforts from different countries within the European Union (EU) incorporated themselves into a single, large stream.

The collective public atmosphere provided impetus to support the OECD's Base Erosion and Profit Shifting (BEPS) Project (OECD BEPS Project or BEPS Project), without which the speed of reform in the international taxation field was regarded as slow and static (Christensen and Hearson 2019). The OECD's Project on Harmful Tax Practices, which started in 1998, delved into the discussion of the OECD BEPS Project in 2013. The impetus of this movement accelerated the push for discussions of reform vis-à-vis complex international tax avoidance by MNEs. The BEPS Project grew quite strong and remarkable, even after discussion of international taxation at the League of Nations.

Even after the final proposal of the BEPS Project was formally issued, the problem of taxation of the digital economy remains on the agenda at the OECD under the title Post-BEPS. At the time this paper was written (August 2020), the discussion of the final approval of the G20 Summit was still ongoing (Johnston 2020b). The G20 and OECD devised a given table, named the Inclusive Framework (IF), for discussion by over 130 countries (Johnston 2020b).

The issue of taxation of the digital economy was left to Post-BEPS because the OECD identified the difficulties the corporate tax system created based purely on the digital economy (OECD 2019b). The development of the digital economy has presented an enormously challenge to the international tax regime involving major MNEs, such as Google, Yahoo, Facebook, Microsoft, Amazon, Apple, and Netflix. The BEPS Project originally focused on the differences between the places of value creation and taxation (OECD 2013). These MNEs have made significant use of the development of digital technology, making these differences more recognizable to tax authorities, the OECD and the G20. Digital technology helps MNEs pass through borders, applying significant pressure on the capacities for taxation of the incomes of these businesses. Digital technology has succeeded well, not only among the tech giants mentioned above, but many other enterprises. Manufacturing businesses can also utilize this technology in its products, often with smart devices. Apparel industries also apply such technology for online shopping, including online payments. Digital technology has become widespread for various industries and businesses, making it the type of infrastructure critical to the development and growth of the economy, both domestically and internationally. Tax authorities and the OECD need to find an appropriate point to tax such a digitalized economy. The OECD BEPS Project concluded that the OECD should work to achieve this, even after 2015 (OECD n.d.-a). 
The Common Reporting Standard (CRS) system, which started in 2014 together with the BEPS Project (OECD n.d.-c), has been promoting automatic exchanges of financial information of taxpayers, among tax authorities (OECD n.d.-c). In another line of tax rulemaking, CRS measures have changed the environment of international taxation.

Research on international taxation from an international relations perspective are not commonplace. Research focusing on the OECD's Project on Harmful Tax Practices, by Sharman (2006) analyzed the project from a constructivist perspective, describing the battle between the major economic countries and so-called tax havens.

The definition of The International Regime by Krasner (1982) is quite popular among research circles. The theory itself has been developed and used to analyze trade systems, security systems, refugee rights, and more generally, human rights. The intersection between the international regime and international taxation, however, is not as popular.

The definition of global governance varies; for example, the United Nations (Committee for Development Policy 2014, vi) state that "[g]lobal governance encompasses the totality of institutions, policies, norms, procedures and initiatives through which [s]tates and their citizens try to bring more predictability, stability and order to their responses to transnational challenges".

Dietsch and Rixen (2016) use an interesting expression in Global Tax Governance, referring to it as "the set of institutions governing issues of taxation that involve cross-border transactions or have other international implications" (1-23), follow the OECD's past projects, such as the Harmful Tax Practices project and Common Reporting Standard (CRS) system. They introduce their discussion with reference to the use of Global Tax Governance. This idea of Global Tax Governance shows greater compatibility with international regimes than the textbook idea of global governance.

This research aims to develop a novel discussion of the international tax regime by exploring recent issues in the field of international tax. The purpose of this paper is to explain the recent international tax regime from a power-basis angle, dividing issues of the regime into the two aspects: tax administration and tax rulemaking.

The aspect of tax administration is related to missions of the Internal Revenue Service (IRS) in the US, while the aspect of tax rulemaking is related to that of the US Department of Treasury. Likewise, in Japan, the former is related to the National Tax Agency, while the latter is related to the Ministry of Finance. For example, the business of tax administration is tax imposition, tax investigation, tax collection, and asset seizure, and the business of tax rulemaking is ruling tax base, tax rate, and timing to tax. In this research, tax administration refers to the implementation and execution of tax rules, or what rule-makers define as the tax system.

It is undeniable that the two aspects are not independent of each other, but rather work together providing feedback to each other. For example, a case of taxation of capital gains is typical. Conceptually, the capital gains are gains that will be taxed, but this is technically impractical for tax administration, implying that tax administration faces limitations in tax rulings. Meanwhile, tax rulings can give legitimate authority to tax administrators. 
Both aspects can involve the same principle. Few would oppose the idea of eliminating double taxation. Facing international double taxation, tax administrators would make the idea a reality, for example, through systems of mutual agreement procedures between tax authorities. To coordinate double taxation, tax rule-makers could define coverage of eligibility of source countries to tax, which would simultaneously define those of resident countries. Battles over eligibility to tax would be difficult because governments' right to tax will directly influence the volume of tax revenue for each government. International conflicts over the right to tax can be troublesome to at the table where the countries are seated (Verdier 2013).

\section{Related insights and knowledge of international relations}

\section{Realism and critical views on liberalism}

International society would fall into anarchy without the control that provides the anarchic society with order. According to Hobbes' view of the state of nature, human beings need state control to maintain their survival, while international society can face anarchy in the absence of an international organization to control of every state (Hobbes 1994).

An anarchic society is marked by struggles among major powers for hegemony, which is the core element of the so-called realist school, which views international society as based on a zero-sum game. Morgenthau (1978, 4-15) argued that a state is a type of apparatus that policymakers utilize to display their power. Hence, the characters of policymakers could significantly influence the execution of state power (Morgenthau 1978, 4-15).

Military force consists of hard power for states, while economic prosperity functions as soft power. President Trump struck out at the World Health Organization (WHO) by stopping payments of the contributions of the US government (Hoffman and Vazquez 2020). American soft power consists of the American private sector. Major MNEs, including Google, Apple, Microsoft, Nike, Starbucks, and Goldman Sachs, contribute to the Gross Domestic Product (GDP) of the US and the revenue of the US government. WHO needs support from the US for assistance in addressing health concerns, particularly within developing countries. This implies that America's economic wealth is a power within international society. Meanwhile, the US, as an economic giant, addressed the problem of nuclear weapons in North Korea (BBC 2019). The US also spread its original anti-money-laundering regulations all over the world via the Financial Action Task Force. The US was the state who first criminalized money laundering, promoted the necessity of regulation throughout the world, and won widespread adoption, even by the famously communist country of China.

Carr $(2001,108)$ stated that "[p]olitical power in the international sphere may be divided, for purposes of discussion, into three categories: (a) military power, (b) economic power, (c) power over opinion." This paper borrows his definition of power. 
Certainly, realism is not the only school of political thought. Proponents of international cooperation derive support from another school, known as liberalism, which claims that international society is a positive-sum game, not a zero-sum game. An example would be the establishment of the League of Nations. With this international institution backed by the liberal ideas of such figures as Woodrow Wilson (Hoffmann 1995), the mood of the international cooperation directly after World War I allowed international society to taste the fruits of labor for peace for a while. The League of Nations, however, failed to stop the subsequent lead into World War II, nor did it last long enough to stop the tragedy of the atomic bomb attacks in Hiroshima and Nagasaki, Japan.

\section{Neorealism and the critical view on neoliberalism}

Neorealism follows the core element of classical realism. It regards state power as systematic and structured. Waltz (1979, 79-160) emphasized the structured power of the state within international society. He also argued that war is not the optimal state (Waltz 1979, 186), and that every country ensures relative gains from others to maintain its survival among other powers within the international society (Waltz 1979, 129-160).

After classical liberalism, another extended school appeared: neoliberalism. Typical of this school are Keohane and Nye, who (1977) stated a new term of complex interdependence, emphasizing economic power as a soft power combining into prominence within the international economy and military power, or so-called hard power. It is certain that international society has been shrinking as globalization has advanced, bringing the economies and financial services of countries around the world into increasingly close inter-connections (Keohane and Nye 1977). Keohane and Nye (1977) insist on the importance of an international system, rules, and organization. Keohane (1984) also argued that various actors, such as non-governmental organizations and MNEs, have achieved a presence within the international society, though states are still pivotal.

Neorealists challenge this neoliberal idea. An example is Joseph M. Grieco. Following the school of Waltz (1979), Grieco (1988) reacted to neoliberalism, maintaining that states are concerned with relative gains, not absolute gains. Consequently, Grieco (1988) claimed that the international system and institutions would not let an involved country gain maximum satisfaction because every country involved is cautious of other parties' cheating, and not of the maximum utility gained through the system or institution.

An example of the neoliberalists is the Association of Southeast Asian Nations plus three (ASEAN plus-3), who are expected to promote regional cooperation for the economy and finance sectors. However, the association has not achieved any remarkable goals. Pempel (2010) pointed out a possible reason for this lack of success, which is that every country involved attempts to figure out the hidden motives of other countries and to err on the side of caution, such that they pursue and acquire their specific interests and gains. In the real world, international cooperation, through international institutions, merely reaches a positive-zero goal. The 
neoliberalists expect this as a shining beacon of hope. Complete trust does not lie among states, as in the textbook scenario of prisoners' dilemma. Potential suspicious to counterparts can divert direction of countries away from Paretian optimum.

\section{International regime theory for this research}

After the Cold War, in the real world, every country increased its degree of interdependency as globalization and free trade entered into the daily human life. International society comprises a mixture of factors, and countries' behaviors are not described perfectly by any of the four schools mentioned above, which are merely idealizations; the real world is described by varied portions taken from each school.

Since the 1980s, the radically fast spread of globalization has been promoting inter-dependency among countries. This implies the relative decrease of the significance of American hard power or military power. Even in such a context, and even after the US became the only leading power after the Soviet dissolution, international society enjoys a certain level of stability and peace. Thus, international regime theory gained attention from scholars of international relations. Steven Krasner's $(1982,186)$ definition of the international regime is the most widely accepted version, which he defined "as sets of implicit or explicit principles, norms, rules, and decision-making procedures around which actors' expectations converge in a given area of international relations."

This theory could be on par with realism because the regime itself can be made based on relative gains among the countries at stake (Grieco 1988). A powerful country can create a regime while pursuing its own gains (Grieco 1988). Although critiques see Krasner's $(1982,186)$ definition of international regime as vague (de Senarclens 1993; Levy, Young, and Zürn 1995), his definition still works as a onesize-fits-all philosophy.

Although this paper borrows the idea of power from Carr $(2001,108)$ and the definition of the international regime from Krasner $(1982,186)$, this paper presupposes that "actors" (Krasner 1982, 186) are not only states, since real international society is not simply composed of states as actors. As ASEAN plus-3 shows, international organizations strengthen its presence, and non-governmental organizations occasionally raise their voices alongside them (Smith 2001; Levi and Murphy 2006). Both actors discuss issues of MNEs' international tax avoidance with state delegates and MNEs input tables for international organizations.

\section{Discussion: a new international tax regime from the BEPS project, Post-BEPS, and CRS system}

This research addresses the new international tax regime from the theoretical basis of international regime theory. The author breaks down the new international tax regime into the BEPS Project, Post-BEPS, and CRS system, showing how the new international regime is formulated based on power, sub-regime by sub-regime. 


\section{BEPS project}

\section{Overview}

The BEPS Project changed gears at the OECD in 2013 upon requests from the G20 Summit (OECD 2019b), issuing 15 Action Plans as its final outcome (OECD 2019b).

The OECD BEPS Project continued for just about two years. The OECD set the table for related discussion and actions by BEPS toward MNEs even before the BEPS Project. For example, they discussed light-footed business income under excessively small tax duties that utilized artificially manipulated tax rules (OECD 1998). They also made great efforts to secure transparency at financial institutions by expanding systems of exchange of information of taxpayers and requiring financial institutions to report the necessary financial information to tax authorities (Sharman 2006; OECD n.d.-c). The OECD has initiated discussions and actions to make the international tax regime fairer in a step-by-step manner. Hence, its pace contrasted with that of the BEPS Project.

The BEPS Project constituted three main axes. According to the OECD (n.d.b, 2-3), these were: "ensur[ing] coherence," "align[ing] taxation and substance," and "ensur[ing] transparency [and] improving certainty." The first corresponded to the set of Action Plans Two to Five (OECD n.d.-b). The second corresponded to Action Plans Six to Ten (OECD n.d.-b). The last corresponded to Action Plans Eleven to Fifteen (OECD n.d.-b).

Even after the end of the OECD BEPS Project, discussion of the new international tax regime is still ongoing at the OECD. However, the fifteen Action Plans of the OECD BEPS Project are inescapable in discussions regarding the international tax regime. These plans would serve to modernize the international corporate tax system and administration while considering the development of their real businesses by MNEs. The OECD $(2016 \mathrm{c}, 1)$ explains that every state "need[s] to ensure that profits are taxed where economic activities generating the profits are performed and where value is created, while at the same time giving businesses greater certainty by reducing disputes over the application of international tax rules and standardising compliance requirements."

Action Plan Fifteen predominantly cultivated legal issues in the developing multilateral tax treaty (OECD 2015a). The tool helped contracting countries override and revise existing bilateral and multilateral tax treaties between countries through one-time adoption, which decreased costs compared to changing existing treaties individually. The task for development of multilateral tax treaty after issuance of Action Plan Fifteen gave way to an ad-hoc group "established on 27 May 2015 with the objective of developing a multilateral instrument to modify existing bilateral tax treaties to swiftly implement the tax treaty measures developed in the course of the OECD-G20 BEPS Project" (OECD 2016a, 1). The adhoc group, with representation from over 100 jurisdictions as of February 2016, brought its outcome as a signature ceremony on June 7, 2017 (OECD 2020a). 


\section{Harmonization and coherence}

Of the fifteen Action Plans, some are aimed at international harmonization or coherence in improving income tax systems, along with BEPS, for MNEs. These are: Action Plans Two ("Neutralizing the Effects of Hybrid Mismatch Arrangements"), Three ("Designing Effective Controlled Foreign Company Rules"), Four ("Limiting Base Erosion Involving Interest Deductions and Other Financial Payments"), and Five ("Countering Harmful Tax Practices More Effectively, Taking into Account Transparency and Substance"; OECD n.d.-a). These are related to the existing tax systems in given countries and are intended to harmonize the patchwork formed by these systems and adjust the former tax regime for MNEs into conformity with BEPS.

Action Plan Two indicated how to address hybrid mismatch arrangements (OECD 2015b), which is resolved by the multilateral instrument of Action Plan Fifteen (OECD 2015b). Action Plan Five regards harmful tax practices, which were still at issue in 2013, being defended as follows: favorable tax treatments could prompt an increase of investments from foreign enterprises, and the GDP of the country invested in could increase. Tax revenue could then increase via withholdings of personal income tax and value added tax.

However, these practices lead to a race to the bottom in tax systems because they tend to follow decreases in corporate tax rates, which could apply pressure to developed countries by decreasing corresponding tax rates. Although developed countries tend to expand their corporate tax base so tax revenues do not decrease when the tax rate decreases, they would not welcome this trend. Furthermore, it would lead to unbalanced redistribution to the invested country, which could decrease trust in the government of the invested country (Rixen 2011). Research shows that government trust positively correlates with tax compliance (Anderson and Tverdova 2003; Cummings et al. 2009). In total, harmful tax practices might sound favorable but would not work as well for the invested and the investing countries.

Such invested countries tend to be developing countries, while the investing countries are developed, such as the members of the OECD and the G20 Summit. The G20 supported Action Plan Five, and the OECD initiated the discussion of Action Plan Five, suggesting that the major economic countries agreed with this policy and institution for the reasons discussed above.

The coherence axis is predominantly related to tax rulemaking. As this subordinate regime brings the prescriptive jurisdiction of each involved country to the table at the OECD, the Action Plans cause conflicts among countries over the distribution of the right to tax. Despite the concerns over Action Plans Two to Five, major economies like the US and Japan have incorporated similar tax rules into their own. The discussion in the OECD Project on Harmful Tax Practices since 1998 should have helped to bring the extended discussion over Action Plan Five to closure, and existing research could give major economies the power to address harmful tax practices. Thus, Plans Two to Five can function to increase the tax revenue of every country.

Although this sub-regime is related to tax rulemaking, major economic powers, and the logic of increases of tax revenue that increase state power in the end, it 
concluded Action Plans Two to Five without much struggle over compromise in the G20 and the OECD.

\section{Taxation and substance}

The fifteen plans included another set of suggestions to modify international standards besides the subgroups on harmonization of the international corporate tax rule. The set consisted of Action Plans Six ("Preventing the Granting of Treaty Benefits in Inappropriate Circumstances"), Seven ("Preventing the Artificial Avoidance of Permanent Establishment Status"), and Eight to Ten ("Aligning Transfer Pricing Outcomes with Value Creation") (OECD n.d.-a). These are the very issues of tax rulemaking and can result in conflicts over national interests.

The final report on the BEPS Project announced Action Plans Six and Seven, which are incorporated into discussion for the multilateral tax treaty of Action Plan Fifteen (OECD 2015c, d).

The other three plans concern soft tax law on transfer pricing and could have caused intense conflicts between the involved countries. Action Plan Eight defines intangible assets and specifies a method to define the points of asset transferring and calculate asset value (OECD n.d.-b). Action Plan Nine concerns risk transfer and excessive capital transfer between affiliated entities (OECD n.d.-b). Action Plan Ten is about the remaining issues of transfer pricing taxation not covered by Action Plans Eight and Nine (OECD n.d.-b). These three plans had been intended to open soft law, brushing up the existing tax system on transfer pricing, to adjust it to BEPS for MNEs.

Action Plan Eight dealt with the intangible assets that tax officers had struggled with, as MNEs utilize transactions with intangible assets for BEPS (OECD 2017). The point that tax officers struggled with in particularly is that there were few comparable transactions to fix the prices of transactions involving intangible assets, such as patents and brands, based on the arm's length principle. Article Nine of the OECD Model Tax Convention refers to the principle, where certain:

conditions are made or imposed between the two enterprises in their commercial or financial relations which differ from those which would be made between independent enterprises, then any profits which would, but for those conditions, have accrued to one of the enterprises, but, by reason of those conditions, have not so accrued, may be included in the profits of that enterprise and taxed accordingly.

Under the arm's length principle, tax administrators would have difficulties in valuing intangible assets, unless the administrators do not have information regarding appropriate comparable transactions. As a matter of fact, major MNEs utilize such hard-to-value transactions to decrease their tax burdens (Committee of Public Accounts, House of Commons n.d.).

This is also because certain MNEs have utilized transactions with tangible assets for BEPS. Even for such transactions, tax officers struggle to find ways to calculate precise values of tangible assets. MNEs, intentionally or unintentionally, have 
decreased their tax burdens by embedding their business transactions with tangible assets (Bergin 2012; European Commission 2015).

The OECD has discussed this issue in its working group, Working Party No. 6 (WP6) (OECD 2020c). WP6 was established in 1973 and contributed to tax rulemaking on transfer pricing, especially towards the end of the 1990s (OECD 2020c). Contributions included the rule related to intangible assets. Although it is true that this discussion has aspects of tax rulemaking and distribution of the right to tax, these discussions cumulatively assisted in getting the parties at the table to settle on the three plans.

It is true that the past discussions helped reach a settlement regarding Plans Eight and Ten. However, given the state of past discussions, Action Plans Eight to Ten, which relate to tax rulemaking, as described above, needed more drivers to reach to an end.

Cooperating major world economies, when formulating the unresolved problem sets of transfer pricing taxation, accelerated discussion of this troublesome issue on the world stage. Before the BEPS Project, the US had a great power over the discussion at the OECD (Azam 2017), including at WP6. The US expanded acceptance of the arm's length principle throughout the world (Avi-Yonah 2007). Although knowledge and theory of economics is important for valuation in the field of transfer pricing, the market power of the US played an influential role in the field, especially in deciding the fair value of transfer pricing from authorities' perspectives. However, the US did not manage to keep up with the pace of development of techniques of transfer pricing: they would have needed a greater impetus to reach a worldwide consensus on the issue as quickly as the OECD BEPS Project had. The European Union (EU) stipulated the momentum of the OECD BEPS Project more strongly. With covering fire from world influential economic actors, the EU and the US, the OECD and G20 converged the discussion at WP6 at full swing. Without momentum, the issue of transfer pricing could still be at stake because it involves tax rulemaking. From the previously discussion related to Action Plans Eight to Ten, initiated predominantly by the US at WP6, the EU strongly shaped the settlement of the Taxation and Substance topic, aside from Action Plans Six and Seven of the BEPS Project.

\section{Transparency and certainty}

Action Plans Eleven to Fourteen dealt with information sharing by tax authorities and means of resolving conflicts over double taxation (OECD n.d.-b). Action Plan Eleven has a different flavor, concerning the data analysis of lost revenue of MNEs due to BEPS (OECD n.d.-b). However, it indirectly indicates the significance of BEPS for MNEs in decreasing corporate tax burdens. Action Plan Twelve required tax authorities to be equipped with disclosure systems that impose requirements on tax promoters to report tax avoidance schemes (OECD n.d.-b). Action Plan Thirteen suggested another disclosure system requiring MNEs to report their business picture to tax authorities, from the whole to minute portions (OECD n.d.-b). Action Plan Fourteen suggested smooth resolution processes and arbitration systems for mutual agreement procedures (OECD n.d.-b). 
Action Plan Fourteen has a mixed character, combining aspects of tax rulemaking and tax administration. The mutual agreement procedures are typically a matter for tax administration staff. However, the mutual agreement procedures commit to the distribution of tax bases between conflicted countries. The swift resolution process gives taxpayers certainty, without being time-consuming, which is helpful even for tax authorities. Tax authorities often need to apply correlative adjustments, in certain cases paying tax refunds with interests corresponding to conflicted periods (OECD 2007). As the procedure becomes longer, interest on tax refund for authorities to pay also gets larger. Therefore, the swift resolution procedure can provide benefits for tax authorities. As Action Plan Fourteen supports the national interests of every involved state, hence it did not raise many issues at the table of the OECD BEPS Project.

Action Plans Twelve and Thirteen attempted to increase information on the part of tax authorities. Action Plan Twelve seemed to contribute to tax rulemaking for anti-BEPS and international tax avoidance. However, the tool itself enabled tax authorities to tax on income by using BEPS, or an artificially processed tax avoidance scheme. Action Plans Twelve and Thirteen brought a fundamental back to tax authorities for appropriate international taxation.

Action Plan Thirteen gives tax authorities greater authority to comprehend MNEs' business outlines and transparency. It also allows for efficient and effective tax administration vis-à-vis powerful MNEs. Action Plan Thirteen thus increases tax revenue, at least for a short period.

As mentioned above, Action Plans Eleven to Fourteen did not include many aspects of tax rulemaking. Rather, they (especially Action Plans Twelve and Thirteen) would serve to bring the former international tax regime into line with the updated regime, giving countries new tools to create a new and balanced playing field among powerful MNEs and formerly powerless tax administrators. Thus, this paper regards this sub-regime of transparency and certainty, especially the transparency portion, as governing the relations between MNEs and states, not between states. In sum, this sub-regime does not hold many implications for struggles between states.

To restore the power of powerless tax administrators vis-à-vis advanced MNE manipulation with complex transfer pricing for BEPS, the state-centric table of the OECD and the G20, including powerful states of the EU and US, advanced discussion of the subject of transparency and certainty at a fast pace. Even though the settled policy of this topic could force MNEs to pay more compliance costs, and the MNEs and private sectors could object to the policy, the states settled the issue over the objections of the MNEs and advanced for appropriate international taxation.

\section{Action plan fifteen}

Action Plan Fifteen concerns the development of multilateral tax treaties related to BEPS. The abovementioned ad-hoc group had initiated this to enact the respective treaties in the real world following the signature ceremony on November 24, 2016. The developed treaty model included coordination of Action Plans Two, Six, Seven and Fourteen. The ceremony entailed signatures by 67 jurisdictions (OECD 2020a). 
Some 92 jurisdictions signed the multilateral treaty by the July 7, 2020 (OECD 2020a).

The multilateral tax treaty might appear to be a tool operating through international cooperation. However, the treaty was formed in subject to a certain power aspect. One of the roles of tax treaties is to give contracting countries a legal basis for addressing double taxation. Another is to improve predictability on the taxpayers' side, whose market power is so strong that aspects of a tax treaty affecting predictability for taxpayers play an important role in their businesses within developed markets. The developed markets, as a result, strongly influence whether developing countries will join the framework of the treaty. If they do so, developing countries can receive money flows from the developed countries, including the G20 and OECD countries. In addition, 67 signatories to the multilateral tax treaty (on November 24, 2016) applied pressure to non-signing countries, threatening them with becoming international pariah (Gruber 2000).

The multilateral tax treaty on Action Plan Fifteen included revisions of the concept of Permanent Establishment (PE). Defining the PE means defining the line between the rights of a source country and those of a resident country regarding the distribution of rights to tax or the national interests that often bring about national conflicts. The proliferation of various types of tax treaties shows that the OECD develops model tax treaties for developed countries, while the United Nations develops model tax treaties for developing countries. The multilateral tool established after the OECD BEPS Project, however, attracted support and prevailed within international society on the back of the economic power of major developed countries and pressure from the signatory countries (Gruber 2000).

\section{After action plan one: ongoing Post-BEPS}

Action Plan One discusses a new corporate tax rule on ongoing digital taxation. The framework for discussion of applying this new taxation to the digital economy after the BEPS Project is generally known as Post-BEPS.

The OECD established an Inclusive Framework (IF) in a conference at Kyoto, Japan, on July 2016 (OECD 2016b). The conference included representatives of 82 jurisdictions (OECD 2016b), which had increased to 137 jurisdictions by December 2019 (OECD 2019a). Upon an equal footing basis among the jurisdictions involved, the IF has been dealing with the new tax rule on the digital economy and tools for implementing the Action Plans of the OECD BEPS Project (OECD 2016b).

The IF listed the new tax rulemaking on the digital economy at the top of its tasks (OECD 2019b). During the period of the BEPS Project, the Task Force on the Digital Economy (TFDE) of the Committee on Fiscal Affairs (CFA) dealt with Action Plan One (OECD 2020b). Under the IF, in January 2017, the TFTD was given another obligation to issue interim reports regarding its progress (by the end of 2018), and a final report by the end of 2020 (OECD 2018a). Accepting a request from the G20, the TFTD opened its interim report during the 2018 IMF/World Bank Spring Meetings in March 2017 (OECD 2018a). In that interim report, the OECD (2018a) argued the necessity of revision of the existing distribution rule and the 
concept of nexus rule, pointing out three main characteristics of a highly digitalized business (HDB): "scale without mass," "heavy reliance on intangible assets," and "data and user participation" OECD (2018a, 212).

Back-to-back with the discussion of the TFTD, US President Trump boldly and rapidly pushed ahead with reforms to a new tax system in the US, including a new international tax system. Two new international tax rules were unveiled under Trump's tax revision of 2017. These are the Base Erosion and Anti-abuse Tax (BEAT), and the Global Intangible Low-Taxed Income (GILTI). BEAT was targeted "largely at foreign companies with major operations in the United States, some of which had for years minimized their United States tax bills by shifting money between American subsidiaries and their foreign parent companies" (Drucker and Tankersley 2019, "Shifting Money"). If this new rule was applied, IRS would tax "some payments that companies sent to their foreign affiliates" by $10 \%$ (Drucker and Tankersley 2019, "Shifting Money"). GILTI was legalized in order "[t]o reduce the benefit companies reaped by claiming that their profits were earned in tax havens," "impos[ing] an additional tax of up to 10.5 percent on some offshore earnings (Drucker and Tankersley 2019, "Shifting Money")."

The government of the US could have an intention to counter the influence of discussions of the European Commission (EC). When analyzing the timeline of its announcement on March 15, 2018, it is clear that the EC must have discussed a new tax rule that targeted US MNEs or HDBs based in America. Originally, the OECD BEPS Project started with great momentum backed by public outrage in the EU toward US MNEs who paid little or no corporate tax in their value creation countries. After the OECD BEPS Project ended in 2015, the OECD did not appear to take effective and rapid action, which would have met the demands of the people in the EU. This seems to have pushed the EC to take action. The European Commission $(2017,3)$ did declare that, "The time to act has now come." The document also stated that the EU needs "a modern tax framework to seize digital opportunities, while also ensuring fair taxation" (European Commission 2017, 6), and "[i]n the absence of adequate global progress, EU solutions should be advanced within the Single Market and the Commission stands ready to present the appropriate legislative proposals" (European Commission 2017, 10). The EC statement should have concerned the US government, showing that the EC might impose unilateral taxation on the US HDBs.

The EU presented a plan of $3 \%$ tax on revenue from digital services, such as online advertisement, platforms and data sales (Becker and Englisch 2018). The US government reacted to this EU action. The US Secretary of the Treasury, Steven Mnuchin (US Department of the Treasury 2018) stated:

The U.S. firmly opposes proposals by any country to single out digital companies. Some of these companies are among the greatest contributors to U.S. job creation and economic growth. Imposing new and redundant tax burdens would inhibit growth and ultimately harm workers and consumers. I fully support international cooperation to address broader tax challenges arising from the modern economy and to put the international tax system on a more sustainable footing. 
According to Drezner's analysis of economic power, the EU is able to counter the US (Drezner 2007, 32-62). The statements of both parties reflect international politics over the economy and tax revenue.

Unfortunately for the EU, several of their members did not keep pace with the major economic powers within the EU (Lampreave 2020), which ended in the failure of the EU plan to direct members to impose taxes on revenue from digital services.

The OECD and IF could have been upset by the battle between the EU and the US. The EU could impose unilateral taxation on MNEs utilizing HDB, thus throwing the international tax regime into chaos. Fortunately for the OECD and IF, the failure of the EU took pressure off the IF. Although the EU tried to step away from the OECD to impose policies reflecting its own interests regarding international taxation, the commitment by the US to the OECD could back the IF business with US market power.

After the international political issue between the EU and US, the IF opened the Programme of Work to Develop a Consensus Solution to the Tax Challenges Arising from the Digitalisation of the Economy Inclusive Framework on BEPS, and received endorsement at the G20 meeting of June 2019 (G20 Finance Ministers and G20 Central Bank Governors 2019a), mandating that the IF wrap up the rulemaking process regarding corporate taxation on the digital economy by the end of 2020 for approval of the G20 Summit by this date. Borrowing the explanation given in the Communiqué Annex of the meeting, this paper describes the two pillars of the plan of the IF as follows: the first pillar, known as Pillar One, "focuses on the allocation of taxing rights, and seeks to undertake a coherent and concurrent review of the profit allocation and nexus rules" (G20 Finance Ministers and G20 Central Bank Governors 2019c, 6). The second, known as Pillar Two, focuses on "the remaining BEPS issues and seeks to develop rules that would provide jurisdictions with a right to 'tax back' where other jurisdictions have not exercised their primary taxing rights or the payment is otherwise subject to low levels of effective taxation" (G20 Finance Ministers and G20 Central Bank Governors 2019c, 6). The logic of the second pillar is quite like that of GILTI. With the press release from G20 Finance Ministers and Central Bank Governors Meeting, Washington D.C., in October 2019, the US influence on IF can be observed. The press release stated that Pillar One is made "to focus on consumer-facing businesses, including highly-digitalized business models" (G20 Finance Ministers and G20 Central Bank Governors 2019b). While the original EU plan was to tax on revenue merely from digital services by HDB enterprises, the expression in this press release included broader tax targets than the target of the original EU plan.

The discussion of corporate taxation in the digital economy did not end at the G20 meetings of 2019. There are two questions here: Could major countries of the EU, backed by public anger, be patient at the end of the 2020? Could one easily suppose that pressured European politicians would feel the need to act against MNEs so as to maintain or increase their popularity within the public? Although the author supposes the answer to the first question is yes and the other no (for international cooperation on the Post-BEPS issue), though not with great confidence, because this tax rulemaking on the digital economy has become a highly political matter (Grinberg 2016), and the political interest of each powerful state 
would be so opaque that the states could not refrain from trying to secure relative gains against other involved partners.

This may be seen in the fact that even after the failure of the EC, major European countries tried to establish a legal basis to tax revenue from HDB of MNEs through the Digital Service Tax (DST). Following such actions from the European countries, the US government reacted strongly. The battle between France and the US was intensive and sensational. The French government announced its action to legalize a bill to tax revenue from the HDB of MNEs (Johnston 2019). The US government maintained its position that the French tax bill would go against the free trade principle of WTO and threatened the French by announcing plans to increase tariffs on products from France (Office of the US Trade Representative 2019). After highly political discussions between the French government and the US government, the battle was suspended by a temporary retreat by the French (Johnston 2019). It is important to note that the UK and Spain are sympathetic to France on this issue, and that the UK Parliament made a bill on DST law (Cui 2019; Johnston 2020f).

While the OECD was embroiled in a power struggle between the major European countries and the US, COVID-19 dealt all parties a severe shock. The promise that the OECD would gain approval of G20 by the end of 2020 started to seem impossible to keep as more French citizens caught the coronavirus. Paris, where the OECD is based, underwent through a lockdown. The slogan of social distance and the powerful infectability of the virus caused abandonment of the original timeline of IF for a virtual, delayed timeline (Johnston 2020a, e). As the number of infected people in the US increased, President Trump lost public support, which brought about a change in the political administrations in the November elections, and hence a change of positions of the US at IF (Johnston 2020c). The OECD staff repeatedly stated that IF would complete its work by the end of 2020 (Johnston 2020d, e), raising criticism that the OECD was overoptimistic in that statement.

Even if IF achieved its goal by the end of 2020, not all involved countries would be able to implement the proposal approved by the G20 Summit. Countries lacking revenue to tackle the coronavirus would be desperate to collect tax from HDB, such as Google and Microsoft, which have collected more users through the enforced solitary lifestyle due to the coronavirus and more revenue because of their popularity. These countries do not seem patient and may remain impatient even after the end of 2020. Some of impatient countries can levy tax on revenue from HDB.

The issue of corporate taxation on the digital economy is likely to keep its position as a highly political issue between powerful countries for a while, if not forever. By accepting criticisms of revenue-basis taxation and due to the lack of opportunity to address issue of double taxation, which could be another cause of the failure of the EC's DST plan, the European power countries may find their own methods to secure their interests, which could throw the new international tax regime into chaos. It is possible that the US, via the OECD, can overcome structural backlash against the DST, and the economic influence of international businesses, even going so far as to manipulate the OECD staff in high positions. The Post-BEPS discussion has aroused the intense interest of involved major countries at and around the OECD and the G20 and will continue to be so. 


\section{The CRS system}

Upon request from the G20, the OECD developed a new automatic exchange of information standard in July 2014, the CRS. The CRS system "calls on jurisdictions to obtain [financial accounting] information [of taxpayers] from their financial institutions and automatically exchange that information with other jurisdictions on an annual basis" (OECD n.d.-c, "What is the CRS?"). Provisions of this new system overlap somewhat with Action Plans Twelve and Thirteen, in that these are all intended to expand tools for tax administrating agencies to secure taxes. The Foreign Account Tax Compliance Act (FATCA) influenced the development of CRS (Hakelberg 2016). The September 11th attack and the financial crisis accelerated the movement to impose closer monitoring of illicit and dark money flow. The US, following this movement, created FATCA. FATCA "requires foreign financial institutions (FFIs) to report to the IRS information about financial accounts held by U.S. taxpayers, or by foreign entities in which U.S. taxpayers hold a substantial ownership interest" (US Department of the Treasury n.d., "FATCA was enacted in 2010 by Congress to target non-compliance by U.S. taxpayers using foreign accounts."). FATCA based the extraterritorial application unilaterally, running up against legal obstacles between jurisdictions. To maintain businesses ties with the powerful US market, each country negotiated with the US authority for a smooth implementation of FATCA, as a result of which the US concluded intergovernmental agreements with each country, easing these obstacles. Thereafter, the US began collecting information based on FATCA. The economic power of the US allowed it to successfully and unilaterally apply the powerful tools through which it collected the foreign financial information of US taxpayers (Hakelberg 2016). The tool of FATCA gave the tax authorities of major countries more motivation for tax transparency, which gave way to the CRS.

Over 60 jurisdictions were positively committed to preparations for the implementation of CRS during May 2014 (OECD 2014). The number of jurisdictions committing to the CRS system later increased to over 100 (OECD 2014). Based on information from FATCA, it is reasonable to assume that interests in expanding tools for tax administration, which would lead to the increase of tax revenue, probably led to the increase in the number of committing countries.

In addition, this peer pressure worked in this case. The 60 jurisdictions that committed to CRS in May 2014 had sufficient influence on the rest of the countries that those countries, to avoid being labelled uncooperative, began to tackle illicit and black money flow (Gruber 2000). This pressure was strong, given the blacklist of the OECD's Project on Harmful Tax Practices and powerful tactics by the Financial Action Task Force (FATF) that consisted of naming and shaming (Aamo 2012). The FATF, as the international programmer for anti-money laundering and terrorist financing, requested that every country identify actual beneficiaries through its Recommendation 24 (FATF 2012). This movement and momentum against illicit money flow, including the FATF action, was backed solidly with support from the G20 (G20 2009). The business of the OECD, which tries to secure the transparency of financial institutions and transactions, including the CRS system, gave way to the Global Forum (OECD 2018b). The issues at the Global Forum and at the FATF 
were endorsed in the same context by G20 quite recently (G20 2009), because the CRS and the FATF have many characteristics in similar. The support from the G20 Summit, powerful consensus on anti-black money and transparency of money flow within international organizations, and many jurisdiction commitments, gave coercive pressure to countries to join the CRS system.

National interests in the expansion of power on tax administration will increase tax revenues and apply peer pressure over departure and objection from the international society, in light of anti-black money and transparency of money flow. This was one driver for the spreading of the CRS system.

The CRS system equips tax administrators with other powerful tools to collect revenue, giving them power to manage and control taxpayers who hide their finances abroad. Supporting countries thus have less incentive to object to strengthening the power of tax administrators over taxpayers to collect revenue appropriately. It should be noted that the motivation to spread this system among supporting countries is similar to that regarding Action Plans Twelve and Thirteen of the BEPS Project.

\section{Conclusion}

This research explained how the new international tax regime was formulated through power. To analyze its components, the author touched on the OED BEPS Project, Post-BEPS, and the CRS system.

With the classification of tax rulemaking and tax administration, this research succeeded in explaining the following four power factors that contributed to the formulation of the new international tax regime: major economic powers, pressures from uncooperative labels, the power of opinion regarding an international tax principle, and the desperate need of tax authorities to ensure the transparency of taxpayers and money flow.

The new international tax regime can be divided into two aspects, depending on the extent to which each sub-regime includes them: international tax rulemaking, and international tax administration. This classification system is useful for analyzing how actors utilize power when formulating the new international tax regime, as it highlights who the main stakeholders are in conflicts of interests over the new international tax sub-regimes.

Issues related to international tax rulemaking illustrate conflicts over interests between countries regarding the distribution of rights to tax, and of the taxable base. Issues of international tax administration are marshaled into conflicts of interests between countries and taxpayers, such as MNEs and individual taxpayers.

The BEPS Project (except for the transparency and certainty portion and PostBEPS) is the sub-regime of the new international tax regime colored by the character of tax rulemaking. Powerful countries with strong economies and markets shaped the process of formulating the sub-regime. In addition, Action Plan Fifteen of the BEPS Project and ongoing Post-BEPS exerted peer pressure through the pressure of opinion as manifested in being labeled uncooperative. The source of peer pressure varied: the initial contracting countries, including major countries, was for Action Plan Fifteen, while IF members more than 100 countries for Post-BEPS. 
The fundamental international tax principle also succeeded in sealing the EC's DST plan. In total, the abovementioned power factors contributed to the formulation of the parts of the new international tax regime related to tax rulemaking.

One should note that Post-BEPS has not concluded, which means that the related tax regime is still in the process of formulation. Post-BEPS concerns the introduction of a new corporate tax system for the digital economy, including HDB of MNEs. It has a character of distribution of the right to tax between countries, particularly major countries. In the context of this system, the EU and the US have come into conflict with each other at the IF of the OECD. Some major European countries plan to tax revenue from digital services as a means of targeting the US MNEs like Google, Amazon, and Netflix. The US countered by preparing for increases of tariffs on products sourced from the respective European countries. The US criticized the DST for proposing to tax revenue, not income, and for making no provisions regarding double taxation. Following this, the US, backed by its market power and power over opinion regarding an international tax principle succeeded in countering European actions for a while and in bringing the major European countries back to the table of the OECD.

COVID-19 struck at the heart of the challenging, tight timeline that the OECD had set. The lack of revenue of major European countries and the prospect of the US presidential election in November made the prospects and road to approval of the G20 unstable. Under these severe conditions, if the OECD succeeded, the success of the new sub-regime creation would be attributed to international cooperation. In reality, however, the US controlled the table, especially against major European countries. If the OECD failed, this would result in the breakaway of the European major powers and decrease the market power and influence of opinion of the US resulting from the damage to the US because of COVID-19 and the new US administration after the election. Nonetheless, the author considers that the momentum of international cooperation is not the basis on which the sub-regime of the Post-BEPS is set.

The sub-regimes of the new international tax regime were predominantly related to tax administration, transparency, and the certainty portion of the BEPS Project and CRS system. They were formulated based on two common power factors: the interests of major economic powers and the desperate need of tax authorities for taxpayer and money flow transparency. In addition, the CRS system was formulated to apply another power factor, similar to the FATF program, which was the pressure to label a country uncooperative. These sub-regimes of international tax administration were easily formed by the power factors managed by every country: they were used to coordinate interests between countries and taxpayers at the country-centric tables of the OECD and the G20. Even though the OECD accepted commitments from private sectors like MNEs, the OECD table was successfully able to parry the opinion and voice of the private sectors and secure fewer troubles among the main voting actors/countries. In sum, certain power factors assisted the part of the new international tax regime related to tax administration when shaping a certain international regime.

A limitation of this research is that it did not include much about the OECD's Project on Harmful Tax Practices. Sharman (2006) dealt with this from the 
constructivist perspective, targeting the recent international tax regime and not the past one. However, a further issue is whether the power perspective could adequately account for the project. Another limitation is that the argument was qualitative discussion.

Despite the abovementioned limitations, this research achieved its aim, by showing that the formulation of the new international tax regime is an accountable area from a power-basis perspective by analyzing the actors in and around the regime through the classification of provisions as reflecting the tax rulemaking or tax administration aspect. The author hopes that this paper will contribute to further research on international taxation from an international relations perspective.

\section{Declarations}

Conflict of interest The authors declare none.

Data availability Any data analysed are included in the paper.

\section{References}

Aamo BS (2012) The importance of the global network in suppressing the financing of terrorism. Presented at the United Nations Special meeting of the Counter-Terrorism Committee, New York, November 20. https://www.fatf-gafi.org/publications/fatfgeneral/documents/theimportanceofthegl obalnetworkinsuppressingthefinancingofterrorism.html. Accessed 19 Aug 2020

Anderson CJ, Tverdova YV (2003) Corruption, political allegiances, and attitudes toward government in contemporary democracies. Am J Polit Sci 47(1):91-109. https://doi.org/10.1111/1540-5907.00007

Associate Press (2012) France Eyes 'Google Tax' for French Websites.' Associate Press, October 30, 2012. https://news.yahoo.com/france-eyes-google-tax-french-websites-194621799--finance.html. Accessed 2 Aug 2020

Avi-Yonah RS (2007) The rise and fall of arm's length: a study in the evolution of U.S. international taxation. In: Law \& economics working papers archive: 2003-2009, p 73. https://repository.law.umich. edu/law_econ_archive/art73. Accessed 1 Aug 2020

Azam R (2017) Ruling the world: generating international tax norms in the era of globalization and BEPS. Suffork Univ Law Rev 50:517-586

BBC (2012) UK uncut protests over Starbucks 'tax avoidance.”’ BBC News, December 8, 2012. https:// www.bbc.com/news/uk-20650945. Accessed 2 Aug 2020

BBC (2019) North Korea and US begin fresh talks on nukes and sanctions. BBC News, October 5, 2019. https://www.bbc.com/news/world-asia-49929914. Accessed 1 Aug 2020

Becker J, Englisch J (2018) EU digital services tax: a populist and flawed proposal. Kluwer International Tax Blog. March 16, 2018. http://kluwertaxblog.com/2018/03/16/eu-digital-services-tax-populistflawed-proposal/. Accessed 1 Aug 2020

Bergin T (2012) Special report: how Starbucks avoids UK taxes. Reuters, October 15, 2012. https://www. reuters.com/article/us-britain-starbucks-tax-idUSBRE89E0EX20121015. Accessed 2 Aug 2020

Carr EH (2001) The twenty years' crisis, 1919-1939: an introduction to the study of international relations. Edited by Michael Cox. Reissued with a new introduction and Additional material. Palgrave, Basingstoke

Christensen RC, Hearson M (2019) The new politics of global tax governance: taking stock a decade after the financial crisis. Rev Int Polit Econ 26(5):1068-1088. https://doi.org/10.1080/09692290. 2019.1625802

Committee for Development Policy (ed) (2014) Global governance and global rules for development in the post-2015 era: policy note. United Nations Publication, New York 
Committee of Public Accounts, House of Commons (n.d) HM Revenue \& Customs: Annual Report and Accounts 2011-12-Nineteenth Report of Session 2012-13." London: House of Commons, UK Parliament. https://publications.parliament.uk/pa/cm201213/cmselect/cmpubacc/716/716.pdf. Accessed 19 Aug 2020

Cui W (2019) The digital services tax on the verge of implementation. Can Tax J 67(4):1135-1152. https://doi.org/10.32721/ctj.2019.67.4.sym.cui

Cummings RG, Martinez-Vazquez J, McKee M, Torgler B (2009) Tax morale affects tax compliance: evidence from surveys and an artefactual field experiment. J Econ Behav Organ 70(3):447-457. https:// doi.org/10.1016/j.jebo.2008.02.010

de Senarclens P (1993) Regime theory and the study of international organizations. Int Soc Sci J 45(4):453-362

Drezner DW (2007) A theory of regulatory outcomes. In: Drezner DW (ed) All politics is global: explaining international regulatory regimes. A theory of regulatory outcomes. Princeton University Press, Princeton. https://doi.org/10.2307/j.ctt7st6p.7

Dietsch P, Rixen T (2016) Global tax governance: what it is and why it matters. Global tax governance: what is wrong with it and how to fix it. ECPR Studies in European Political Science. ECPR Press, Colchester, pp 1-23

Drucker J (2012) Google revenues sheltered in no-tax bermuda soar to \$10 billion. Bloomberg, December 10, 2012. https://www.bloomberg.com/news/articles/2012-12-10/google-revenues-sheltered-inno-tax-bermuda-soar-to-10-billion. Accessed 18 Aug 2020

Drucker J, Tankersley J (2019) How big companies won new tax breaks from the trump administration. The New York Times, December 30, 2019, sec. Business. https://www.nytimes.com/2019/12/30/ business/trump-tax-cuts-beat-gilti.html. Accessed 1 Aug 2020

European Commission (2015) Commission decides selective tax advantages granted by Luxembourg and the Netherlands to fiat and starbucks are illegal under EU state aid rules. Text. European Commission. October 21, 2015. https://ec.europa.eu/commission/presscorner/detail/en/IP_15_5880. Accessed 2 Aug 2020

European Commission (2017) A fair and efficient tax system in the European union for the digital single market. European Commission, Brussels. https://doi.org/10.1163/2210-7975_HRD-4679-0058

FATF (2012) International standards on combating money laundering and the financing of terrorism \& proliferation. FATF, Paris. http://www.fatf-gafi.org/media/fatf/documents/recommendations/pdfs/ FATF\%20Recommendations\%202012.pdf. Accessed 7 Aug 2020

G20 (2009) London summit-leaders' statement: 2 April 2009. G20, London. https://www.imf.org/exter nal/np/sec/pr/2009/pdf/g20_040209.pdf. Accessed 1 Aug 2020

G20 Finance Ministers and G20 Central Bank Governors (2019a) G20 finance ministers and central bank governors' meeting, Fukuoka, Communiqué. G20, Fukuoka. https://www.mof.go.jp/english/inter national_policy/convention/g20/communique.pdf. Accessed 7 Aug 2020

G20 Finance Ministers and G20 Central Bank Governors (2019b) G20 press release on international taxation. G20, Washington D.C. https://www.mof.go.jp/english/international_policy/convention/g20/ 191018it.pdf. Accessed 7 Aug 2020

G20 Finance Ministers and G20 Central Bank Governors (2019c) Summary of the programme of work to develop a consensus solution to the tax challenges arising from the digitalisation of the economy. G20, Fukuoka. https://www.mof.go.jp/english/international_policy/convention/g20/annex10_3.pdf. Accessed 1 Aug 2020

Grieco JM (1988) Anarchy and the limits of cooperation: a realist critique of the newest liberal institutionalism. Int Organ 42(3):485-507

Grinberg I (2016) The new international tax diplomacy. Georgetown Law J 104:1137-1196

Gruber L (2000) Ruling the world: power politics and the rise of supranational institutions. Princeton University Press, Princeton

Hakelberg L (2016) Redistributive tax co-operation: automatic exchange of information, US power and the absence of joint gains. Global tax governance: what is wrong with it and how to fix it. ECPR studies in European political science. ECPR Press, Colchester, pp 123-156

Hobbes T (1994) Leviathan: with selected variants from the latin edition of 1668. Edited by E. M. Curley. Hackett Pub. Co, Indianapolis

Hoffmann S (1995) The crisis of liberal internationalism. Foreign Policy 98:159. https://doi.org/10.2307/ 1148964 
Hoffman J, Vazquez M (2020) Trump announces end of US relationship with World Health Organization. CNN, May 29, 2020. https://www.cnn.com/2020/05/29/politics/donald-trump-world-health-organ ization/index.html. Accessed 1 Aug 2020

Johnston SS (2019) U.S. and France strike compromise over digital services tax. Taxnotes. August 27, 2019. https://www.taxnotes.com/tax-notes-today-international/digital-economy/us-and-francestrike-compromise-over-digital-services-tax/2019/08/27/29w73. Accessed 28 July 2020

Johnston SS (2020a) OECD postpones key meeting of global tax overhaul project. Taxnotes. May 4, 2020. https://www.taxnotes.com/featured-news/oecd-postpones-key-meeting-global-tax-overhaulproject/2020/05/04/2ch38. Accessed 21 June 2020

Johnston SS (2020b) OECD chief warns of 'messy' outcome without digital tax deal. Taxnotes. May 22, 2020. https://www.taxnotes.com/featured-news/oecd-chief-warns-messy-outcome-without-digitaltax-deal/2020/05/22/2ckb4. Accessed 26 May 2020

Johnston SS (2020c) Let's build on cooperation for digital tax deal, OECD chief says. Taxnotes. July 2, 2020. https://www.taxnotes.com/tax-notes-today-international/digital-economy/lets-build-coope ration-digital-tax-deal-oecd-chief-says/2020/07/02/2cp81. Accessed 28 July 2020

Johnston SS (2020d) OECD aims to have global tax deal blueprints ready in October. Taxnotes. July 14, 2020. https://www.taxnotes.com/tax-notes-today-international/digital-economy/oecd-aims-haveglobal-tax-deal-blueprints-ready-october/2020/07/14/2cq87. Accessed 28 July 2020

Johnston SS (2020e) OECD sketches out progress on global tax reform blueprints. Taxnotes. July 23, 2020. https://www.taxnotes.com/tax-notes-today-international/base-erosion-and-profit-shiftingbeps/oecd-sketches-out-progress-global-tax-reform-blueprints/2020/07/23/2crcr. Accessed 28 July 2020

Johnston SS (2020f) U.K. digital services tax becomes law, stoking trade tensions. Taxnotes. July 23, 2020. https://www.taxnotes.com/tax-notes-today-international/digital-economy/uk-digital-servicestax-becomes-law-stoking-trade-tensions/2020/07/23/2cr9q. Accessed 28 July 2020

Keohane RO (1984) Cooperation and international regimes. After hegemony: cooperation and discord in the world political economy. Princeton University Press, Princeton, pp 49-64

Keohane RO, Nye JS (1977) Realism and complex interdependence. Power and interdependence: world politics in transition. Little, Brown, Boston, pp 23-37

Krasner SD (1982) Structural causes and regime consequences: regimes as intervening variables. Int Organ 36(2):185-205

Lampreave P (2020) Spain has approved the digital service tax: the controversy is served. Kluwer International Tax Blog. February 24, 2020. http://kluwertaxblog.com/2020/02/24/spain-has-approvedthe-digital-service-tax-the-controversy-is-served/. Accessed 27 July 2020

Levi M, Murphy GH (2006) Coalitions of contention: the case of the WTO protests in Seattle. Polit Stud 54(4):651-670. https://doi.org/10.1111/j.1467-9248.2006.00629.x

Levy MA, Young OR, Zürn M (1995) The study of international regimes. Eur J Int Rel 1(3):267-330. https://doi.org/10.1177/1354066195001003001

Morgenthau HJ (1978) Politics among nations: the struggle for power and peace, 5th edn. Knopf, New York

OECD (n.d.-a) BEPS 2015 final reports. OECD.Org. https://www.oecd.org/ctp/beps-2015-final-reports. htm. Accessed 31 July 2020

OECD (n.d.-b) BEPS frequently asked questions. OECD, Paris. https://www.oecd.org/ctp/BEPS-FAQsE nglish.pdf. Accessed 29 July 2020

OECD (n.d.-c) Common reporting standard (CRS). OECD.Org. https://www.oecd.org/tax/automaticexchange/common-reporting-standard/. Accessed 1 Aug 2020

OECD (1998) Harmful tax competition. OECD, Paris

OECD (2007) Manual on effective mutual agreement procedures (MEMAP). OECD, Paris. https://www. oecd.org/ctp/38061910.pdf. Accessed 18 Aug 2020

OECD (2013) Addressing base erosion and profit shifting. OECD. https://doi.org/10.1787/9789264192 744-en

OECD (2014) Standard for automatic exchange of financial account information in tax matters, 1st edn. OECD, Paris

OECD (2015a) Developing a multilateral instrument to modify bilateral tax treaties, action 15-2015 final report. OECD/G20 Base Erosion and Profit Shifting Project. OECD, Paris. https://doi.org/10. 1787/9789264241688-en 
OECD (2015b) Neutralising the effects of hybrid mismatch arrangements, Action 2-2015 final report. OECD/G20 Base Erosion and Profit Shifting Project. OECD, Paris. https://doi.org/10.1787/97892 64241138-en

OECD (2015c) Preventing the artificial avoidance of permanent establishment status, action 7-2015 Final Report. OECD/G20 Base Erosion and Profit Shifting Project. OECD, Paris. https://doi.org/10. $1787 / 9789264241220$-en.

OECD (2015d) Preventing the granting of treaty benefits in inappropriate circumstances, action 6-2015 final report. OECD/G20 Base Erosion and Profit Shifting Project. OECD, Paris. https://doi.org/10. 1787/9789264241695-en.

OECD (2016a) BEPS action 15: development of a multilateral instrument to implement the tax treaty related BEPS measures. OECD, Paris. https://www.oecd.org/tax/treaties/BEPS-Discussion-draftMultilateral-Instrument.pdf. Accessed 1 Aug 2020

OECD (2016b) First meeting of the new inclusive framework to tackle base erosion and profit shifting marks a new era in international tax co-operation. OECD.Org. 2016. https://www.oecd.org/tax/beps/ first-meeting-of-the-new-inclusive-framework-to-tackle-base-erosion-and-profit-shifting-marks-anew-era-in-international-tax-co-operation.htm. Accessed 1 Aug 2020

OECD (2016c) Explanatory statement to the multilateral convention to implement tax treaty related measures to prevent base erosion and profit shifting. OECD, Paris. https://www.oecd.org/tax/treat ies/explanatory-statement-multilateral-convention-to-implement-tax-treaty-related-measures-toprevent-BEPS.pdf. Accessed 29 July 2020

OECD (2017) BEPS action 8: implementation guidance on hard-to-value intangibles. OECD, Paris. https://www.oecd.org/ctp/transfer-pricing/BEPS-implementation-guidance-on-hard-to-value-intan gibles-discussion-draft.pdf. Accessed 1 Aug 2020

OECD (2018a) Tax challenges arising from digitalisation-interim report 2018: inclusive framework on BEPS. OECD/G20 Base Erosion and Profit Shifting Project. OECD, Paris. https://doi.org/10.1787/ 9789264293083-en. Accessed 7 Aug 2020

OECD (2018b) Tax transparency 2018: report on progress. OECD, Paris. https://www.oecd.org/tax/trans parency/global-forum-annual-report-2018.pdf. Accessed 1 Aug 2020

OECD (2019a) Members of the OECD/G20 inclusive framework on BEPS. OECD. https://www.oecd. org/tax/beps/inclusive-framework-on-beps-composition.pdf. Accessed 1 Aug 2020

OECD (2019b) OECD/G20 inclusive framework on BEPS: progress report July 2018-May 2019. OECD, Paris. https://www.oecd.org/tax/beps/inclusive-framework-on-beps-progress-report-july-2018-may2019.pdf. Accessed 1 Aug 2020

OECD (2020a) Multilateral convention to implement tax treaty related measures to prevent base erosion and profit shifting: information brochure. OECD, Paris. https://www.oecd.org/tax/treaties/multilater al-instrument-BEPS-tax-treaty-information-brochure.pdf. Accessed 5 Aug 2020

OECD (2020b) Statement by the OECD/G20 inclusive framework on BEPS on the two pillar approach to address the tax challenges arising from the digitalisation of the economy. OECD, Paris. https:// www.oecd.org/tax/beps/statement-by-the-oecd-g20-inclusive-framework-on-beps-january-2020.pdf. Accessed 1 Aug 2020

OECD (2020c) Working party no.6 on the taxation of multinational enterprises. On-Line Guide to OECD Intergovernmental Activity. April 28, 2020. https://oecdgroups.oecd.org/Bodies/PrintBodyView. aspx?BodyID=1666\&amp;BodyPID=12235\&BodyHID=0\&amp;Lang=en. Accessed 31 July 2020

Office of the US Trade Representative (2019) USTR announces initiation of section 301 investigation into France's digital services tax. Office of the US Trade Representative. July 10, 2019. https://ustr. gov/about-us/policy-offices/press-office/press-releases/2019/july/ustr-announces-initiation-section301. Accessed 1 Aug 2020

Pempel TJ (2010) Soft balancing, hedging, and institutional Darwinism: the economic-security nexus and east Asian regionalism. J East Asian Stud 10(2):209-238. https://doi.org/10.1017/S159824080 0003441

Remeur C (2018) Listing of tax havens by the EU. European Parliamentary Research Service. https:// www.europarl.europa.eu/cmsdata/147412/7\%20-\%2001\%20EPRS-Briefing-621872-Listing-taxhavens-by-the-EU-FINAL.PDF. Accessed 19 Aug 2020

Rixen T (2011) Tax competition and inequality: the case for global tax governance. Glob Gov Rev Multilateral Int Org 17(4):447-467. https://doi.org/10.1163/19426720-01704004

Sharman JC (2006) Havens in a storm: the struggle for global tax regulation. Cornell studies in political economy. Cornell University Press, Ithaca 
Smith J (2001) Globalizing resistance: the battle of Seattle and the future of social movements. Mobil Int Q 6(1):1-19. https://doi.org/10.17813/maiq.6.1.y63133434t8vq608

US Department of the Treasury (n.d.) Foreign account tax compliance act. US Department of the Treasury. https://home.treasury.gov/policy-issues/tax-policy/foreign-account-tax-compliance-act. Accessed 1 Aug 2020

US Department of the Treasury (2018) Secretary Mnuchin statement on OECD's Digital Economy Taxation Report. US Department of the Treasury. March 16, 2018. https://home.treasury.gov/news/pressreleases/sm0316. Accessed 19 Aug 2020

Verdier P-H (2013) The political economy of international financial regulation. Indian Law J 88(4):1405-1474

Waltz KN (1979) Theory of international politics, 1st edn. McGraw-Hill, Boston 